\title{
Modification of Snack Bar Cheubit with Addition of Seaweed (Eucheuma Cottonii) and Beet (Beta Vulgaris L.) as a Snack Alternative for Elementary School Children Obesity
}

\author{
Faradillah Farida ${ }^{1)}$, Agus Heri Santoso ${ }^{2)}$ and Nur Rahman ${ }^{2)}$ \\ 1) Student of the D-IV Nutrition Study Program, Department of Nutrition, Politeknik Kesehatan \\ Kemenkes Malang \\ 2) Lecturer of the D-IV Nutrition Study Program Lecturer, Department of Nutrition, Politeknik \\ Kesehatan Kemenkes Malang \\ E - mail : rahmancahaya@yahoo.com
}

\begin{abstract}
Obesity has become a nutritional problem in Indonesia. The prevalence of obesity in children aged 5-12 years in Indonesia is quite high, namely $8.0 \%$, while the prevalence of obesity in East Java is above the national rate (> 8.0\%). Efforts to prevent and cope with obesity in children need to be done, one of them by making the snack alternative like snack bar with the addition of seaweed and beet. Seaweed and beet is a good ingredient for obesity because it has high fiber content and low fat. The aim of this research is to know the effect of Modification of Snack Bar Cheubit with Addition of Seaweed (Eucheuma cottonii) and Beet (Beta vulgaris L.) as a Snack Alternative for Elementary School Children Obesity to fiber content, chemical quality, energy value, and organoleptic quality. The research type was laboratory experiment with Randomized Complete Random Design (RAL) design using 3 treatment levels, is the proportion of wheat flour: seaweed: beet is P1 (10:54:15), P2 (10:49:20), and P3 (10: $44: 25)$. Each formulation is done 3 times replication so that there are 9 units of research. The results of the statistical test using Oneway Anova showed that the proportion of seaweed and beet gave no significant difference to fiber content, protein content, fat content, moisture content, ash content, carbohydrate content, and energy value of snack bar. Assessment of organoleptic qualities using the Kruskal Wallis statistical test with advanced MannWhitney test gave a significant difference to color, taste, and texture, however, a not significant difference to the aroma of the snack bar. The best treatment level is P3 treatment level in 100 gram which contains energy value 209,86 kcal, protein 3,08 gram, fat 2,99 gram, carbohydrate 42,67 gram and fiber 2,12 gram.
\end{abstract}

Keywords: Obesity, Seaweed, Beet, Snack Bar

\section{INTRODUCTION}

The nutritional problem that is currently happening in Indonesia is a dual nutritional problem, where the problem of undernutrition has not been fully resolved, but overnutrition has emerged. Excess nutrition that causes obesity can occur in children to adulthood.

Supplementary food for school children is given to meet the nutritional adequacy of elementary school age children (Juknis PMT,
2017). Elementary school age children are usually called middle age children. The middle age period is the age period of 6-12 years (Santrock, 2009). In school-age children, they need good nutrition, considering that this age is entering a period of growth, development, and puberty. Good nutrition will produce healthy and productive teenagers to adults. At that age, they tend to like to eat snacks. According to Maarisit et al. (2014), children have a habit of snacking outside. However, consuming 
snacks incorrectly can have an impact on body health, one of which is obesity.

The 2010 Basic Health Research (Riskesdas) obtained data on the prevalence of obese children (overnutrition and obesity) aged 612 years reaching $9.2 \%$ at the national rate (Balitbangkes RI, 2010). Data from the 2013 Basic Health Research for the national prevalence of obese children aged 5-12 years was $18.8 \%$, consisting of $10.8 \%$ overweight and $8.8 \%$ very obese (Balitbangkes RI, 2014). The prevalence of overweight (overweight) in school-age children (6-12 years) in East Java Province also increased by $12 \%$ in 2010 and in 2013 by $12.4 \%$ (Ministry of Health, 2010; 2013). This shows an increase in the incidence of obesity in children aged 5-12 years from 2010-2013.

Fiber has an influence on obesity, especially soluble fiber. Soluble fiber will slow gastric emptying time, increasing transit time (Tala, 2009). This can make you feel full longer and reduce hunger. As is known, Eucheuma cottonii seaweed has a fairly high soluble fiber content, which is $18.25 \mathrm{~g} / 100 \mathrm{~g}$ (Matanjun et al., 2008). Beets also have a fairly high fiber content.

Seaweed (seaweeds) type Eucheuma cottonii in general has been widely used on an industrial scale, among others, for raw materials for medicines, cosmetic raw materials, raw materials for health food, raw materials for processed food products (Sutomo, 2006 in Handayani and Aminah, 2011) . Research results Astawan et al. (2005) showed that the addition of $5 \%$ and $10 \%$ TRL (Seaweed Flour) into the diet was able to significantly reduce the total cholesterol levels of rats under hypercholesterolemic conditions to equal the total cholesterol levels of normal rats (negative control group). The addition of TRL to the diet of hypercholesterolemic rats can reduce total cholesterol, LDL, triglycerides and atherogenic index.

Beets are a potential source of fiber and various vitamins and minerals that can be used as a potential source of antioxidants (Wirakusumah, 2007). The results of Khristivanie's research (2017) showed that oral administration of beetroot extract (Beta vulgaris. L) reduced F2 Isoprostane levels in the urine of rats that were given excess activity. As is known, the increase in F2Isoprostane as a product of lipid peroxidation causes oxidative stress.

Efforts to prevent and overcome obesity in school children need to be done, one of which is by making practical alternative snacks such as snack bars. Snack bars are snacks in the form of bars. Snack bars are a source of energy because the main ingredients are flour, sugar and fat. These snacks are generally poor in various bioactive components such as antioxidants, fiber (dietary fiber), and minerals that play an important role in health. Healthy snacks are not only rich in energy, but should also contain fiber, protein, antioxidants, various vitamins and minerals that are important for health (Christian, 2011).

This study aims to determine the fulfillment of snack bars with the addition of seaweed (Eucheuma cottonii) and beets (Beta vulgaris L.) as an alternative snack for obese elementary school children to nutrients according to the calculation of the formulation.

\section{METHODS}

This research is an experimental type of research in the field of food. The experimental design used in this study was a completely randomized design (CRD) using 3 treatment levels, namely the proportion of wheat flour: seaweed: beetroot with the principle of a Low Energy Diet according to Almatsier (2009), namely low energy, sufficient protein, moderate fat (unsaturated fat). saturated), rather low carbohydrates (preferably complex carbohydrates), and high fiber as a basis for determining proportions. Each treatment level was replicated 3 times so that the number of research units was 9 research units.

The development of this formula is designed to meet the nutrition of the Low Energy Diet and developed into isocalories which refers to $1500 \mathrm{kcal}$ energy, $15 \%$ protein, $20 \%$ fat, and $65 \%$ carbohydrates. From the isocaloric principle, the amount and type of material used is the same, however, the proportion of one or two ingredients is different for each treatment level.

The main ingredients in making Cheubit snack bars are Eucheuma cottonii seaweed and 
beets. Eucheuma cottonii seaweed and beets come from the big market of Malang city. Other ingredients used in making Cheubit snack bars are wheat flour, sugar, raisins, and sesame.

This research was conducted in AprilMay 2018. The research was conducted at the Food Technology Science Laboratory (ITP) Department of Nutrition at the Health Polytechnic of the Ministry of Health of Malang for the snack bar processing. THP Food Quality and Safety Testing Laboratory, Faculty of Food Technology, Universitas Brawijaya Malang for analysis of chemical quality (protein content, fat content, water content, ash content, and carbohydrate content) snack bar, Nutrition Laboratory, Faculty of Animal Husbandry, University of Muhammadiyah Malang for analysis of snack bar fiber content and State Elementary School Experiment 2 Malang to test the organoleptic quality of snack bars.

The process of making Cheubit snack bars begins with cleaning the seaweed and beets. After that, add the flour, sugar, and raisins then add the blended seaweed and beets, mix until the dough is smooth. The next process is weighing the dough and divided into equal parts, each 50 grams. Each dough is molded into a rectangular shape, then sprinkled with sesame on the entire surface of the snack bar dough and baked at $1500 \mathrm{C}$ for 60 minutes.

The untrained panelists used in this study in the organoleptic quality test were 25 students at the Experimental State Elementary School 2 Malang and the determination of the best treatment level using the effectiveness index method with 25 semi-trained panelists. Data processing and analysis techniques include data processing on the effect of adding seaweed and beets to fiber content, chemical quality, and energy value of snack bars with One Way Anova statistical analysis at a 95\% confidence level and organoleptic quality data with Kruskal Walis statistical analysis at a 95 confidence level.

\section{RESULTS AND DISCUSSION}

Fiber Content

Table 1. shows the average fiber content of the Cheubit snack bar at each treatment level, where the highest fiber content was found in the P3 treatment.

Table 1. Average Fiber Content of Cheubit Snack Bar Each Treatment Level

\begin{tabular}{cc}
\hline Treatment Level & $\begin{array}{c}\text { Average Fiber } \\
\text { Content }(\%)\end{array}$ \\
Wheat flour: Seaweed: Beet) & $1,99^{\mathrm{a}}$ \\
$\mathrm{P}_{1}(10: 54: 15)$ & $1,93^{\mathrm{a}}$ \\
$\mathrm{P}_{2}(10: 49: 20)$ & $2,12^{\mathrm{a}}$ \\
$\mathrm{P}_{3}(10: 44: 25)$ & \\
\hline
\end{tabular}

The results of Oneway Anova statistical analysis at the $95 \%$ confidence level $(\mathrm{p}=0.05)$ showed that the addition of seaweed and beets gave an insignificant difference $(p=0.842)$ to the fiber content of the Cheubit snack bar.

The difference in fiber content at each level of Cheubit snack bar treatment is influenced by its constituent materials. The fiber content of beetroot is 2.8 grams/100 grams higher than the fiber content of seaweed, which is 1.39 grams $/ 100$ grams. However, the fiber content of the Cheubit snack bar showed an insignificant difference because the fiber content of seaweed and beets were both high enough so that the fiber content of the snack bar produced was approximately the same. The fiber content in Cheubit snack bars ranges from 1.93-2.12 grams/100 grams. As for the fiber needs of children aged 6-12 years, which is \pm 20 -30 grams / day (AKG, 2013) so that the fiber content in the Cheubit snack bar has met $10 \%$ of the fiber needs of children for snack fulfillment. Cheubit snack bar fiber should be higher because the soluble fiber content in seaweed is $18.2 \mathrm{~g} / 100$ $\mathrm{g}$, however, in this study, the fiber analyzed was crude fiber, so the fiber obtained tended to be lower.

\section{Chemical quality}

The average chemical quality levels, namely protein content, fat content, water content, ash content, and carbohydrate content of Cheubit snack bars for each treatment level are presented in Table 2.

Neway Anova statistical analysis results on the level of confidence $95 \%(\mathrm{p}=0,05)$ showed that the addition of seaweed and beets gave no significant difference, respectively $(\mathrm{p}=0,725$, $\mathrm{p}=0,618, \mathrm{p}=0,582, \mathrm{p}=0,628, \mathrm{p}=0,671)$ on protein content, fat content, moisture content, ash content, and carbohydrate content of Cheubit snack bar. 
Tabel 2. Average Chemical Quality Level of Cheubit Snack Bar for Each Treatment Level

\begin{tabular}{|c|c|c|c|c|c|}
\hline \multirow{2}{*}{$\begin{array}{c}\text { Treatment } \\
\text { Level } \\
\text { (Wheat } \\
\text { Flour: } \\
\text { Seaweed: } \\
\text { Beet) }\end{array}$} & \multicolumn{5}{|c|}{ Average (\%) } \\
\hline & $\begin{array}{l}\text { Content } \\
\text { Protein }\end{array}$ & $\begin{array}{l}\text { Content } \\
\text { Lipid }\end{array}$ & $\begin{array}{l}\text { Content } \\
\text { Water }\end{array}$ & $\begin{array}{l}\text { Content } \\
\text { Ash }\end{array}$ & $\begin{array}{l}\text { Content } \\
\text { Carbohidrat }\end{array}$ \\
\hline $\begin{array}{c}\mathrm{P}_{1} \\
(10: 54: 15)\end{array}$ & $3,27^{\mathrm{a}}$ & $3,48^{\mathrm{a}}$ & $45,27^{\mathrm{a}}$ & $2,97^{\mathrm{a}}$ & $45,01^{\mathrm{a}}$ \\
\hline $\begin{array}{c}\mathrm{P}_{2} \\
(10: 49: 20)\end{array}$ & $3,49^{\mathrm{a}}$ & $3,12^{\mathrm{a}}$ & $45,04^{\mathrm{a}}$ & $2,92^{\mathrm{a}}$ & $45,43^{\mathrm{a}}$ \\
\hline $\begin{array}{c}\mathrm{P}_{3} \\
(10: 44: 25)\end{array}$ & $3,08^{\mathrm{a}}$ & $2,99^{\mathrm{a}}$ & $48,14^{\mathrm{a}}$ & $3,13^{\mathrm{a}}$ & $42,67^{\mathrm{a}}$ \\
\hline
\end{tabular}

The difference in protein content for each level of Cheubit snack bar treatment is influenced by the constituent ingredients. The protein content of seaweed is higher at 5.12 grams/100 grams compared to the protein content of beets, which is 1.6 grams $/ 100$ grams. However, the protein content of the Cheubit snack bar showed an insignificant difference because the proportion of seaweed given did not differ much at each treatment level so that the protein content of the snack bar produced was approximately the same. The protein content in the Cheubit snack bar ranges from 3.08-3.49 grams/100 grams. The protein content does not meet the protein needs of snacks (10\% of the requirement) according to the empirical calculation standard, which is 5.62 grams/100 grams. It can be caused by heating. In the process of making snack bars, the oven temperature used is $150 \mathrm{oC}$ for 60 minutes. Heating is a processing process that uses high temperatures. The higher the temperature, the protein will be hydrolyzed and denatured (Zaitsev et al., 1969 in Suwandi, 1990). Elviani's (2013) research showed that with an increase in temperature every $10^{\circ} \mathrm{C}$, from $45^{\circ} \mathrm{C}$ to $95^{\circ} \mathrm{C}$, each heated for 15 minutes, 30 minutes, 45 minutes, and 60 minutes there was a decrease in protein content so that the conclusion of the study was that the higher the heating temperature, the lower the protein content. protein, and the longer the heating time, the lower the protein content of the white swallow's nest.

The insignificant difference in the fat content of the Cheubit snack bar is influenced by its constituent materials, where the fat content in seaweed and beets is both low, namely the fat content of seaweed is 0.13 grams $/ 100$ grams and beets are 0.18 grams $/ 100$ grams so that the fat content of the Cheubit snack bar produced is approximately the same. The fat content in Cheubit snack bars ranges from 2.99-3.48 grams $/ 100$ grams. The fat content has met the needs of snack fat (10\% needs) according to the empirical calculation standard, which is 3.33 grams/100 grams.

The difference in water content for each level of Cheubit snack bar treatment is influenced by the constituent materials. The water content of the beetroot is higher at 87.58 grams/100 grams compared to the water content of the seaweed, which is 12.9 grams $/ 100$ grams, so that at $\mathrm{P} 3$, the Cheubit snack bar has the highest water content. The properties of seaweed are hydrogels, where these properties can bind water in a product. Hydrogel is a type of hydrophilic polymer macromolecule in the form of a cross-linked network, has the ability to expand in water (swelling), and has a high water diffusion power. Hydrogels are also soft and have a high water content (Utomo et al., 2016). In addition, seaweed and beets do not go through a drying or flouring process so that the moisture content of Cheubit snack bars tends to be higher than other commercial snack bars which usually use dry ingredients. This causes the moisture content of the Cheubit snack bar to be relatively high and exceeds the moisture content of the biscuits according to SNI 01-2973-1992, which is a maximum of $5 \mathrm{~g} / 100 \mathrm{~g}$.

The difference in the ash content of the Cheubit snack bar is influenced by its constituent materials, namely the proportion of beets given. That's because beets are quite high as a source of vitamins and minerals. Heating food containing minerals at high temperatures will produce more ash, because the ash is composed of minerals (Sitoresmi, 2012). Murray (2003) also states that the high ash content means the high content of mineral elements in food ingredients or products. Food ingredients consist of about $96 \%$ organic matter and water, the rest consists of mineral elements, namely inorganic substances or also called ash content. The mineral elements contained in beets include iron, magnesium, 
phosphorus, potassium, sodium, ascorbic acid, vitamin $\mathrm{A}$, vitamin $\mathrm{D}$, vitamin $\mathrm{E}$, vitamin $\mathrm{K}$, and others.

The difference in the carbohydrate content of the Cheubit snack bar is influenced by differences in other chemical qualities, namely the moisture, ash, protein, and fat content of the snack bar. The carbohydrate content of an ingredient is inversely proportional to other nutrients. The higher the value of all or one of these nutrients, the lower the carbohydrate content (Tresnani, 2016). From the results of the study, it was known that the lowest carbohydrate content was at the P3 treatment level, where the highest P3 treatment level was in the water content and ash content. Carbohydrate levels in Cheubit snack bars range from 42.67-45.43 grams/100 grams. The carbohydrate content exceeds the need for snack carbohydrates (10\% of needs) according to the empirical calculation standard, which is 24.37 grams/100 grams. This can be due to the relatively low protein and fat content of the Cheubit snack bar, resulting in high carbohydrates.

\section{CONCLUSIONS}

The addition of seaweed and beets gave an insignificant difference to the fiber content, chemical quality (protein content, fat content, moisture content, ash content, and carbohydrate content), and the energy value of the Cheubit snack bar.

The addition of seaweed and beetroot gave a significant difference to the color, taste, and texture, however, there was an insignificant difference to the aroma of the Cheubit snack bar.

\section{REFERENCES}

Almatsier, S. 2009. Prinsip Dasar Ilmu Gizi. Gramedia Pustaka Utama, Jakarta.

Astawan, M., Tutik, W., dan Anzs, B. H. 2005. Pemanfaatan Rumput Laut sebagai Sumber Serat Pangan untuk Menurunkan Kolesterol Darah Tikus. Jurnal Hayati, 12 (1) : 23-27.

Balitbang Kemenkes RI. 2010. Riset Kesehatan Dasar; RISKESDAS. Balitbang Kemenkes RI, Jakarta.

Balitbang Kemenkes RI. 2013. Riset Kesehatan Dasar; RISKESDAS. Balitbang Kemenkes
RI, Jakarta.

Christian, M. 2011. Pengolahan Banana Bars Dengan Inulin Sebagai ALternatif Pangan Darurat. Skripsi. Institut Pertanian Bogor, Bogor.

Elviani, Y. 2013. Efek Suhu Dan Jangka Waktu Pemanasan Terhadap Kadar Protein Yang Terkandung Dalam Sarang Burung Walet Putih (Collocalia Fuciphagus). Tesis. Fakultas Kedokteran. Universitas Kristen Maranatha Bandung. Bandung.

Handayani, R. dan Aminah, S. 2011. Variasi Substitusi Rumput Laut Terhadap Kadar Serat Dan Mutu Organoleptik Cake Rumput Laut (Eucheuma Cottonii). Jurnal Pangan dan Gizi, 3 (2) : 67-74.

Herbach, K.M., F.C. Stinizing and R. Carle. 2006. Betalain stability and degradation structural and chromatic aspects. J. Sci. of food. Vol, 71. Nr.4.

Khristivanie, Y. 2017. Pemberian Ekstrak Etanol Umbi Bit Merah (Beta vulgaris. L) Oral dapat Menurunkan Kadar F2-Isoprostan pada Urin Tikus (Rattus Norvegicus) Wistar Jantan yang Diinduksi Aktivitas Fisik Berlebih. Tesis, Fakultas Kedokteran, Universitas Udayana, Denpasar.

Maarisit, C. L., Sarimin, S., dan Babakal, A. 2014. Hubungan Pengetahuan Orang Tua Tentang Demam Tifoid Dengan Kebiasaan Jajan Pada Anak di Wilayah Kerja RSUD Mala Kecamatan Melonguane Kabupaten Kepulauan Talaud. Program Studi Ilmu Keperawatan Fakultas Kedokteran Universitas Sam Ratulangi. Manado.

Matanjun P., S. Mohamed, Mustapha, N.M., Muhammad, K., and Ming, C.H. 2008. Antioxidant activities and phenolics content of eight species of seaweed from north Borneo. J. Appl Phycol. 20 : 367-373.

Mejcher, M. A. and H. J. Henryk. 2005. Identification of Potent Odorants Formed During the Preperation of Extruded Potato Snacks. J. Agric Food Chem, 53:6432-6437.

Murray, R.K., Granner, D.K., Mayes, P.A., dan Rodwell, V.W. 2003. Biokimia Harper. 
Edisi 25. EGC, Jakarta.

Palupi, N.S., Zakaria, F.R. dan Prangdimurti, E. 2007. Pengaruh pengolahan terhadap nilai gizi pangan, modul e-learning ENBP. IPB: Departemen Ilmu \& Teknologi PanganFateta-IPB.

Petunjuk Teknis PMT. 2017. Pemberian Makanan Tambahan (Balita-Ibu Hamil-Anak Sekolah). Kementerian Kesehatan RI, Jakarta.

Pradipta, I. 2011. Karateristik Fisikokimia dan Sensori Sack Bar dengan Penambahan Salak Pondoh Kering. Skripsi. Fakultas Pertanian Universitas Sebelas Maret. Surakarta.

Santrock, John W. 2009. Perkembangan Anak. Erlangga, Jakarta.

Sari, Y. 2018. Pengaruh Pemanasan Terhadap Kestabilan Pigmen Betalain Dari Buah Naga Merah (Hylocereus Polyrhizus). Jurnal Pendidikan Kimia, 2 (1) : 37-42.

Sitoresmi, K.M.A. 2012. Pengaruh Lama Pemanggangan dan Ukuran Tebal Tempe terhadap Komposisi Proksimat Tempe Kedelai. Jurnal Publikasi.
Suwandi R. 1990. Pengaruh proses penggorengan dan pengukusan terhadap sifat fisiko-kimia protein ikan mas (Cyprinus carpio). Tesis. Institut Pertanian Bogor, Bogor.

Tala, Z.Z. 2009. Manfaat Serat Bagi Kesehatan. USU, Medan.

Tresnani, R. A. 2016. Substitusi tepung komposit ubi jalar kuning (ipomea Batatas L.) dan kecambah kedelai (Glycine Max Merr) pada pembuatan snack bar forvita bagi balita gizi buruk fase rehabilitasi terhadap mutu kimia, nilai energi, mutu protein, mutu fisik dan mutu oraganoleptik. Skripsi, Jurusan Gizi, Politeknik Kemenkes Malang, Malang.

Utomo, B.S.B., Fransiska, D., dan Darmawan, M. 2016. Formulasi Hidrogel Dari Polivinil Pirolidon Dan k/l- Karaginan Untuk Bahan Pembalut Luka. JPB Kelautan dan Perikanan, Vol. 11 No. 1 : 55-66.

Widyaningrum, M. L. dan Suhartiningsih. 2014. Pengaruh Penambahan Puree Bit (Beta vulgaris) Terhadap Sifat Oraganoleptik Kerupuk. E-journal Boga, 1 (3) : 233-238.

Wirakusumah, E. 2007. Buah Dan Sayur Untuk Terapi. Penerbit Swadaya, Jakarta. 